\title{
Promotive effect of pyridine on the biodegradation of isoquinoline by activated sludge under denitrifying conditions
}

\author{
Lin Wang, Lijuan Sun, Yongmei Li* \\ State Key Laboratory of Pollution Control and Resources Reuse, \\ School of Environmental Science and Engineering, Tongji University, \\ Shanghai, China
}

\begin{abstract}
Lab-scale batch experiments were conducted to investigate the promotive effect of pyridine on the biodegradability of isoquinoline under denitrifying conditions. The effect of $\mathrm{pH}$ and temperature on the biodegradation of isoquinoline in the presence of pyridine were also investigated. The biodegradation of isoquinoline was significantly influenced by $\mathrm{pH}$ and temperature. At $\mathrm{pH}$ of 7.5 , both isoquinoline and pyridine were completely removed, whereas at $\mathrm{pH}$ of 6.5 and 8.0, isoquinoline was only removed by $84 \%$ and $86 \%$, respectively. The high $\mathrm{pH}$ even inhibited the degradation of pyridine. While pyridine was completely degraded in the temperature range of 20-35 ${ }^{\circ} \mathrm{C}$, isoquinoline was removed by $90 \%$ only in the temperature range of $28-30^{\circ} \mathrm{C}$. When the concentration ratio of isoquinoline to pyridine was in the range of 10:1 and 2:1, pyridine accelerated the degradation of isoquinoline; however, pyridine exhibited inhibition effect on the biodegradation of isoquinoline when the ratio reached 1:1.
\end{abstract}

Keywords- promotive effect; isoquinoline; pyridine; activated sludge; denitrifying conditions

\section{INTRODUCTION}

$\mathrm{N}$-heterocyclic aromatic compounds such as quinoline, isoquinoline, pyridine etc. have received immense attention, because of their persistent, toxic, recalcitrant and carcinogenic nature $[1,2]$. They are rated as priority pollutants by USEPA (United States Environmental Protection Agency) [3, 4]. These compounds could occur naturally in the environment; however, the majority of these compounds come from human activities. They are generated from manufacturing of dyes, explosives, pesticides and pharmaceuticals, also from mining industry, coal tar, oil shale processing operation, wood preserving facilities and chemical manufacturing plants [4-6]. Wastewater containing these compounds must be treated before being discharged into the environment, to prevent the damage to natural ecosystems and humankind. Comparing with chemical and physical methods, biological treatment has been accepted as one of the most feasible, eco-friendly and cost-effective options. A lot of researchers have investigated their biodegradation by using them as sole carbon and energy source [5, 7-12]. However, the tolerance of microorganisms towards the exhibited toxicity of these compounds is not unlimited. High concentrations of these compounds may change the activity of one or more enzymes, affect enzyme synthesis by interaction with genome or transcription process, alter cell's permeability and finally influence the total functional activity

Foundation item: The National Natural Science Foundation of China (No. 50108009) and the State Key Laboratory of Pollution Control and Resource Reuse, China (Grant no. PCRRCF07001 and PCRRY08009).

* Corresponding author. Tel.: +86 21 65982693; Fax: +86 2165986313.

E-mail address: liyongmei@tongji.edu.cn of the cell [13]. In order to prevent the unfavorable impacts on cell metabolism when dealing with complex mix wastewater, researches must be done. In the wide majority of cases, conventional carbon sources at low concentrations stimulate microbial growth and thus more enzymes are available in order to degrade more recalcitrant compounds [14]. Another issue, that has to be pointed out is the importance of culture history on the effective biodegradation of priority pollutants, since it affects strongly the physiological state of the cells, meaning their macromolecular composition, which is the synthesis and reaction of enzyme systems [15].

Illuminating by above theories, in this paper two typical Nheterocyclic aromatic compounds, isoquinoline and pyridine were chosen. Pyridine only has single ring, resulting in the readily access by enzymes[16], whereas isoquinoline has nitrogenous heterocyclic and benzene ring. The increased molecular size made it more difficult for enzymes to access. Solubility also affects the degradability of compounds. The solubility of pyridine is much higher than isoquinoline, which may be another reason for the recalcitrant of isoquinoline. Previous research has confirmed that under denitrifying conditions, pyridine was easily degraded, whereas isoquinoline was more difficulty to be degraded [17]. In this study, pyridine was used as co-substrate, the promotive effect of pyridine on isoquinoline degradation under denitrifying conditions by activated sludge was investigated. Effects of $\mathrm{pH}$ and temperature on the biodegradation of isoquinoline in the presence of pyridine were also studied. The objective of the study is to provide useful information for the treatment of wastewater containing the mixture of $\mathrm{N}$-heterocyclic aromatic compounds.

\section{MATERIALS AND METHODS}

\section{A. Bioreactors}

The bioreactor for acclimating activated sludge and degradation experiment was made of plexiglass, with diameter of $150 \mathrm{~mm}$ and height of $520 \mathrm{~mm}$. The working volume was 9 $\mathrm{L}$, the wastewater was filled at the height of $510 \mathrm{~mm}$, resulting in $10 \mathrm{~mm}$ of head space above the water surface. In order to ensure anaerobic conditions, the top of the bioreactor was sealed by a plexiglass lid after filling. The dissolved oxygen remained in the $10 \mathrm{~mm}$ head space was consumed soon after the acclimation began, and couldn't been detected by the dissolved oxygen apparatus (DO5510HA, Taiwan). The reactor 
was run by the mode of SBR (Sequencing Batch Reactor). The wastewater was filled in the reactor, then the mixed liquid was stirred until isoquinoline and pyridine was completely degraded. The solution was then settled and the supernatant was drawed to the half of the working volume.

The bioreactor for the experiment investing the effect of $\mathrm{pH}$ and temperature on the biodegradation was made of plexiglass,

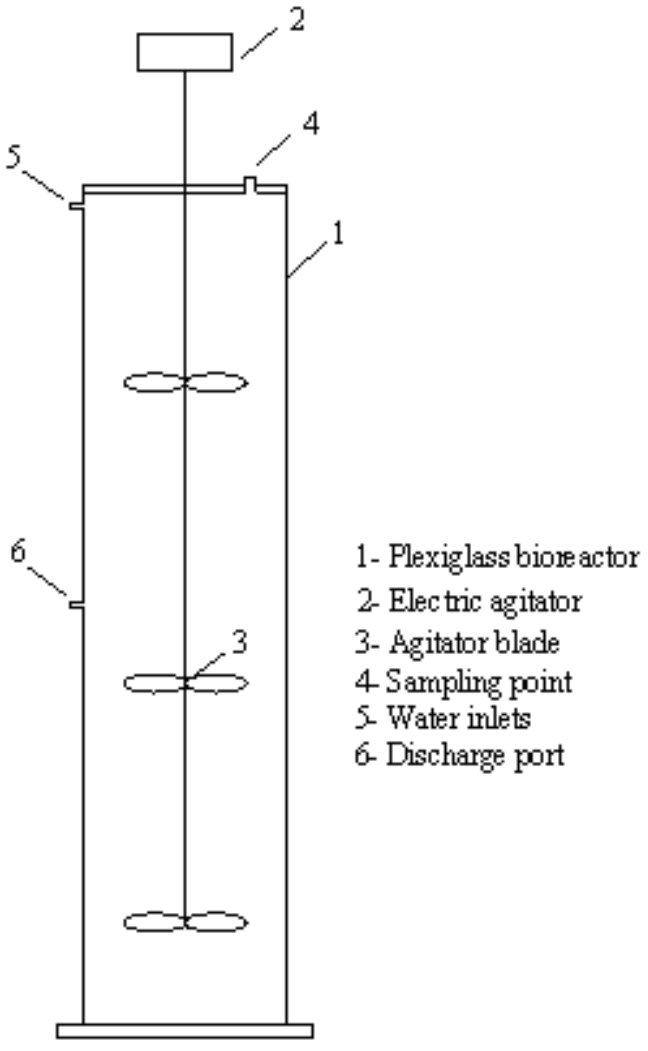

(a) with diameter of $80 \mathrm{~mm}$ and height of $210 \mathrm{~mm}$. The working volume was $1 \mathrm{~L}$. In order to ensure anaerobic conditions, the top of the bioreactor was also sealed by a plexiglass lid after filling. The bioreactor was conducted to investigate influencing factors during degradation like $\mathrm{pH}$ and temperature. The schematic figures of the two bioreactors were shown in Fig 1.

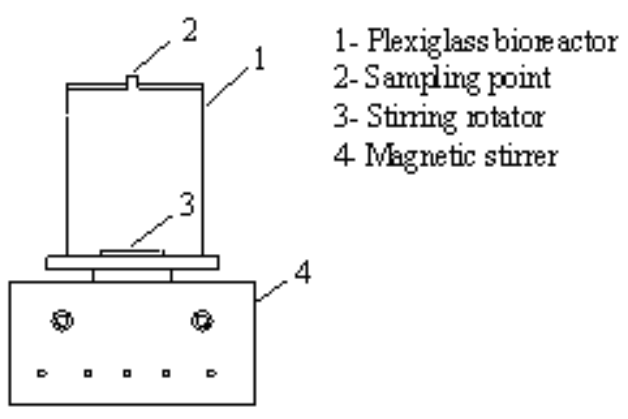

(b)

Figure 1. The bioreactors used in the experiment. (a) bioreactor for acclimating activated sludge and degradation experiment, (b) bioreactor for studying the effect of $\mathrm{pH}$ and temperature.

\section{B. Chemicals}

Isoquinoline and pyridine were obtained from Sigma chemical co. (St. Louis, MO, USA) and was used to prepare the media. Synthetic wastewater was prepared using tap water and supplemented with isoquinoline and pyridine at different ratios. Sodium nitrate was supplemented at the desired ratio of chemical oxygen demand (COD) to $\mathrm{NO}^{-}-\mathrm{N}$. Phosphorus $\left(\mathrm{KH}_{2} \mathrm{PO}_{4}\right)$, calcium $\left(\mathrm{CaCl}_{2}\right)$, and magnesium $\left(\mathrm{MgSO}_{4}\right)$ were used at radio of COD: $\mathrm{P}: \mathrm{Ca}: \mathrm{Mg}=100: 1: 0.18: 0.18$. The COD was the calculated oxygen demand based on isoquinoline or pyridine as the carbon sources, and organic nitrogen was oxidized to nitrate. The COD was calculated according to the following equations

$$
\begin{aligned}
& \mathrm{C}_{9} \mathrm{H}_{7} \mathrm{~N}+12 \mathrm{O}_{2}+\mathrm{OH}^{-} \rightarrow 9 \mathrm{CO}_{2}+4 \mathrm{H}_{2} \mathrm{O}+\mathrm{NO}_{3}^{-}(1) \\
& \mathrm{C}_{5} \mathrm{H}_{5} \mathrm{~N}+7.5 \mathrm{O}_{2}+\mathrm{OH}^{-} \rightarrow 5 \mathrm{CO}_{2}+3 \mathrm{H}_{2} \mathrm{O}+\mathrm{NO}_{3}^{-}(2)
\end{aligned}
$$

where $1.0 \mathrm{~g}$ of isoquinoline is equivalent to $2.98 \mathrm{~g}$ of $\mathrm{COD}$, and $1.0 \mathrm{~g}$ of pyridine is equivalent to $3.03 \mathrm{~g}$ of COD.

\section{Analyses}

Samples used for isoquinoline and pyridine quantification were taken periodically from the bioreactors, and filtered through a $0.45 \mu \mathrm{m}$ cellulose ester membrane. Samples were extracted with dichloromethane three times and then dried by anhydrous sodium sulphate. The concentration of isoquinoline and pyridine of each prepared sample was determined with a gas chromatography (Agilent 6890) equipped with flame ionization detector and $30.0 \mathrm{~m} \times 320 \mathrm{um} \times 0.25 \mathrm{um}$ (insider diameter) stainless-steel column (HP-5). Injector and detector temperatures were kept at 250 and $280^{\circ} \mathrm{C}$, respectively. The column temperature was stayed at $100{ }^{\circ} \mathrm{C}$ for $1 \mathrm{~min}$, then increase at the rate of $10^{\circ} \mathrm{C} / \mathrm{min}$ to $160^{\circ} \mathrm{C}$, and kept on $2 \mathrm{~min}$. Nitrogen was used as the carrier gas.

Measurement of nitrite, ammonia nitrogen and COD (chemical oxygen demand) were according to standard methods [18]. Because isoquinoline was absorbs strongly at 
220 and $275 \mathrm{~nm}$, nitrate was measured by rapid spectorphotometric determination using phenol [19].

\section{RESULTS AND DISCUSSION}

\section{A. Effects of initial $p H$}

In the experiments investigating the effect of $\mathrm{pH}$ on the biodegradation of isoquinoline, the initial concentrations of isoquinoline and pyridine were both $100 \mathrm{mg} / \mathrm{L}$. Previous studies indicated that the optimal $\mathrm{C} / \mathrm{N}$ (the concentration ratio of $\mathrm{COD}$ to $\mathrm{NO}_{3}{ }^{-} \mathrm{-N}$ ) ratios for both isoquinoline and pyridine degradation under denitrifying conditions were 8 to 10 when isoquinoline and pyridine were used as the sole carbon sources, respectively. Therefore, the $\mathrm{C} / \mathrm{N}$ ratio was set at around 10 in this experiment. The initial $\mathrm{pH}$ of the wastewater was controlled at $6.5,7.0,7.5$ and 8.0 by phosphate buffer solution, except one sample was not adjusted $\mathrm{pH}$. The reaction time was controlled at 10 hours. The results were shown in Table I. $\mathrm{pH}$ played an important role in the degradation of isoquinoine and pyridine. Pyridine was completely degraded when $\mathrm{pH}$ was in the range of 6.5-7.5, whereas when $\mathrm{pH}$ at 8.0, its removal efficiency was only $55 \%$, indicating the inhibition effect of high $\mathrm{pH}$ on the biodegradation of $\mathrm{N}$-heterocyclic compounds. The optimal $\mathrm{pH}$ for the biodegradation of isoquinoine was 7.5. Around this $\mathrm{pH}$ value more than $95 \%$ isoquinoline was removed, whereas at $\mathrm{pH}$ of 6.5 and 8.0 , the removal efficiencies of isoquinoline were only $84 \%$ and $86 \%$, respectively.

TABLE I. EFFECTS OF INITIAL PH ON THE DEGRADATION WHEN CONCENTRATION RATIO OF ISOQUINOLINE TO PYRIDINE WAS 1:1

\begin{tabular}{|c|c|c|c|c|c|c|c|c|}
\hline \multicolumn{4}{|c|}{ Influent $(\mathrm{mg} / \mathrm{L})$} & \multicolumn{4}{|c|}{ Effluent $(\mathrm{mg} / \mathrm{L})$} & \multirow{2}{*}{$\begin{array}{c}\text { RE-Iso }(\% \\
)\end{array}$} \\
\hline Isoq & Pyr & $\mathrm{NO}_{3}{ }^{-}-\mathrm{N}$ & $\mathrm{pH}$ & Iso & Pyr & $\mathrm{NO}_{3}{ }^{-}-\mathrm{N}$ & $\mathrm{pH}$ & \\
\hline \multirow{5}{*}{100} & \multirow{5}{*}{100} & \multirow{5}{*}{60.11} & $7.39^{*}$ & 4.96 & n.d. & 37.18 & 8.25 & 95.05 \\
\hline & & & 6.5 & 15.59 & n.d. & 37.51 & 7.69 & 84.41 \\
\hline & & & 7.0 & 9.35 & n.d. & 37.38 & 7.44 & 90.65 \\
\hline & & & 7.5 & n.d. & n.d. & 34.89 & 7.00 & 100 \\
\hline & & & 8.0 & 13.35 & 45.04 & 48.05 & 8.01 & 86.65 \\
\hline
\end{tabular}

Notes: Isoq: concentration of isoquinoline; Pyr: concentration of pyridine; RE-Isoq: removal efficiency of isoquinoline; *: the sample whose $\mathrm{pH}$ was not adjusted; n.d.: not detected.

\section{B. Effects of temperature}

In the experiments investigating the effect of temperature on the biodegradation of isoquinoline, the initial concentrations of isoquinoline and pyridine were both $100 \mathrm{mg} / \mathrm{L}$, and the $\mathrm{C} / \mathrm{N}$ ratio was 10 . The initial $\mathrm{pH}$ in the bioreactors was controlled at 7.5 , and the reaction time was controlled at $24 \mathrm{~h}$. The reactors were run at the temperature of $20,25,28,30$ and $35^{\circ} \mathrm{C}$, respectively, by thermostatic magnetic agitator (85-2, China). The results were shown in Table II. The temperature played an

TABLE II. EFFECTS OF TEMPERATURE ON THE DEGRADATION OF ISOQUINOLINE AND PYRIDINE

\begin{tabular}{|c|c|c|c|c|c|c|}
\hline \multirow{2}{*}{$\mathrm{T}\left({ }^{\circ} \mathrm{C}\right)$} & \multicolumn{5}{|c|}{ Effluent $(\mathrm{mg} / \mathrm{L})$} & RE-Iso $(\%$ \\
\cline { 2 - 5 } & Isoq & Pyr & $\mathrm{NO}_{3}{ }^{-}-\mathrm{N}$ & $\mathrm{NO}_{2}{ }^{-}-\mathrm{N}$ & $\mathrm{NH}_{3}-\mathrm{N}$ & ) \\
\hline 20 & 49.66 & n.d. & 37.68 & 35.47 & 19.59 & 50.34 \\
\hline 25 & 13.66 & n.d. & 23.53 & 20.47 & 22.90 & 86.34 \\
\hline 28 & 3.32 & n.d. & 4.54 & 3.98 & 31.33 & 96.68 \\
\hline 30 & 6.84 & n.d. & 9.51 & 23.94 & 25.63 & 93.16 \\
\hline 35 & 12.34 & n.d. & 6.11 & 14.60 & 36.23 & 87.66 \\
\hline
\end{tabular}

Notes: Isoq: concentration of isoquinoline; Pyr: concentration of pyridine; REIsoq: removal efficiency of isoquinoline; n.d.: not detected.

\section{Promotive effect of pyridine on the biodegradation of isoquinoline}

Different concentration ratio of isoquinoline to pyridine was chosen to proceed the experiments, as 10:1, 6:1, 4:1, 2:1 and 1:1. Fig 2 shows that an increase of pyridine concentration in the wastewater led to faster isoquinoline degradation. This indicates that pyridine can promote the degradation of isoquinoline. important role in the biodegradation of isoquinoine and pyridine. At the five temperatures, all the pyridine was degraded in $24 \mathrm{~h}$. When the temperature was $20^{\circ} \mathrm{C}$, isoquinoline was only removed by $50 \%$. In the range of $25-35{ }^{\circ} \mathrm{C}$, isoquinoline was well degraded, The optimal temperature range was $28-30{ }^{\circ} \mathrm{C}$, in which more than $90 \%$ isoquinoline was removed.

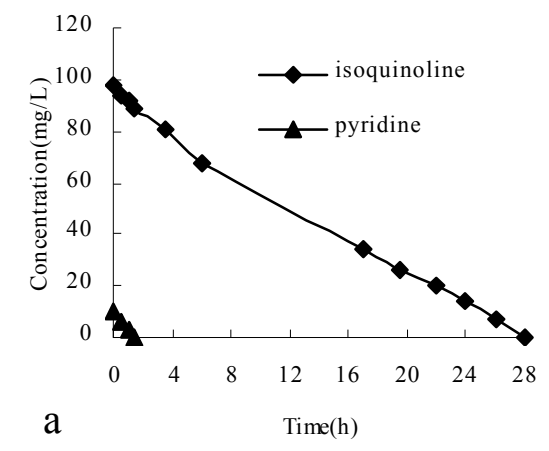



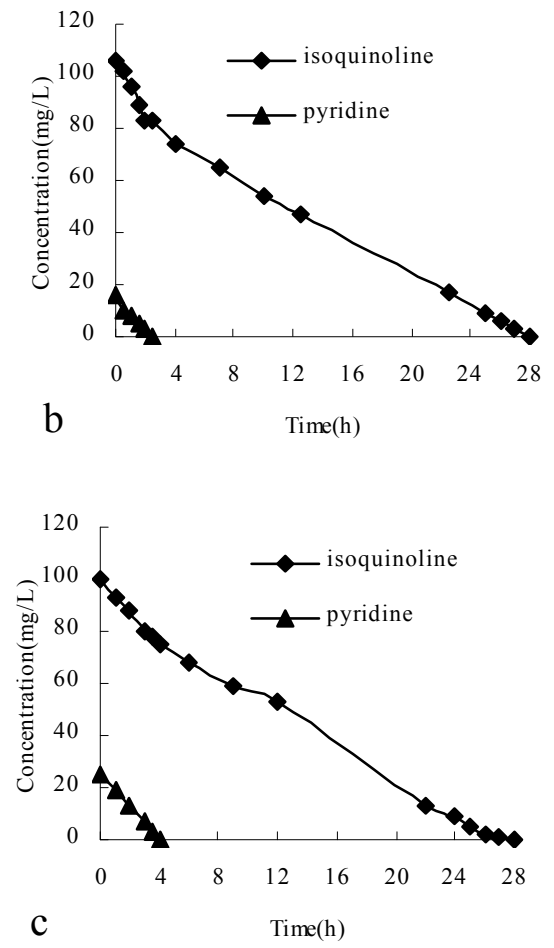
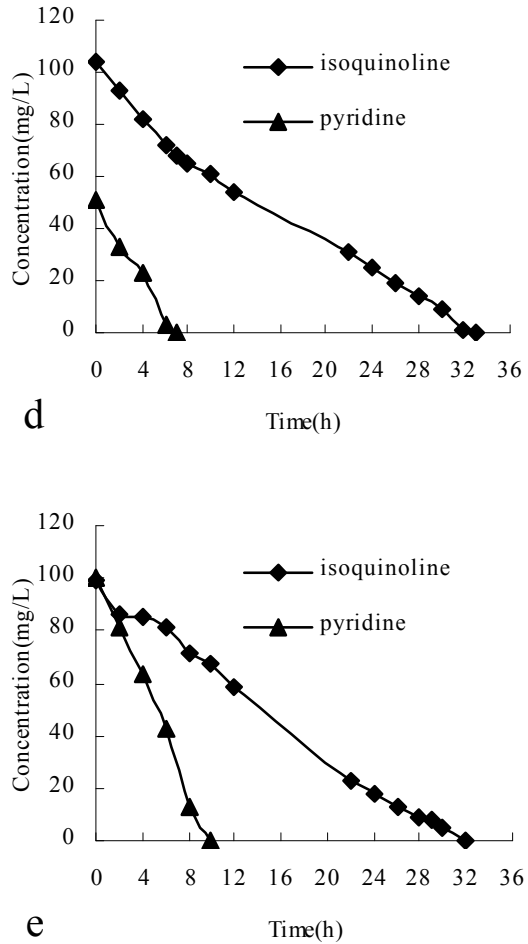

Figure 2. Degradation of isoquinoine and pyridine at different concentration ratios of isoquinoine to pyridine. (a) 10:1, (b) 6:1, (c) 4:1, (d) 2:1 and (e) 1:1.

TABLE III. KINETIC EQUATIONS AND THE SPECIFIC DEGRADATION RATE OF ISOQUINOLINE IN THE PRESENCE AND ABSENCE OF PYRIDINE

\begin{tabular}{|c|c|c|c|c|c|c|c|c|}
\hline Isoq/Pyr & Time range & Equation & $\begin{array}{c}\mathrm{K} \\
\left(10^{-3} / \mathrm{h}\right)\end{array}$ & $\mathrm{R}^{2}$ & $\begin{array}{l}\text { Time } \\
\text { range }\end{array}$ & Equation & $\begin{array}{c}\mathrm{K}^{*} \\
\left(10^{-3} / \mathrm{h}\right)\end{array}$ & $\mathrm{R}^{2}$ \\
\hline $10: 1$ & $0 \sim 1.5 \mathrm{~h}$ & $y=-5.279 t+96.881$ & 1.313 & 0.9756 & $1.5 \sim 28 \mathrm{~h}$ & $y=-3.252 t+90.847$ & 0.820 & 0.9960 \\
\hline $6: 1$ & $0 \sim 2.5 \mathrm{~h}$ & $y=-10.321 t+106.02$ & 2.356 & 0.9698 & $2.5 \sim 28 \mathrm{~h}$ & $y=-3.1023 t+87.137$ & 0.708 & 0.9975 \\
\hline $4: 1$ & $0 \sim 4.0 \mathrm{~h}$ & $y=-6.4579 t+100.16$ & 1.497 & 0.9984 & $4.0 \sim 28 \mathrm{~h}$ & $y=-3.273 t+88.472$ & 0.759 & 0.9951 \\
\hline $2: 1$ & $0 \sim 7.0 \mathrm{~h}$ & $y=-5.1206 t+103.3$ & 1.247 & 0.9967 & $7.0 \sim 33 \mathrm{~h}$ & $y=-2.6527 t+87.864$ & 0.646 & 0.9960 \\
\hline $1: 1$ & $0 \sim 10 \mathrm{~h}$ & $y=-2.97 t+96.582$ & 0.751 & 0.9490 & $10 \sim 32 \mathrm{~h}$ & $y=-3.0572 t+94.729$ & 0.773 & 0.9860 \\
\hline
\end{tabular}

Notes: Isoq/Pyr: concentration ratio of isoquinoline to pyridine; K: specific degradation rate of isoquinoline in the presence of pyridine;

$\mathrm{K}^{*}$ : specific degradation rate of isoquinoline in the absence of pyridine.

Pyridine always completely degraded prior to isoquinoline, and isoquinoline degraded much slower. The degradation of pyridine conformed to zero model and its specific degradation rate increased along with its concentration. The reason was pyridine could be easily degraded, when degradation with isoquinoline, it used as preferential carbon source easily degraded by microorganism, moreover, with its concentration increasing the advantage was more markedly. The degradation rate of isoquinoline appeared different in the presence and absence of pyridine, and it was shown in Table III.

Except for the ratio $1: 1$, at all the other four ratios, the specific degradation rate of isoquinoline in the presence of pyridine was greater than that in the absence of pyridine. The reason was the existence of pyridine could accelerate the degradation of isoquinoline. However, when the concentration of pyridine arrived at high concentration of $100 \mathrm{mg} / \mathrm{L}$, it exhibited the inhibition for isoquinoline degradation. The reason was that the existence of pyridine induced to synthesize the critical enzyme for N-heterocyclic aromatic compounds degradation, and the enzyme also could be utilized by isoquinoline. However, if the concentration of pyridine was too high, pyridine may compete with isoquinoline on the critical enzyme, and degradation of isoquinoline was inhibited as pyridine could utilize the enzyme more easily. So, pyridine could accelerate the degradation of isoquinoline under their concentration ratio between 10:1-2:1, but much higher concentration of pyridine inhibited the degradation of isoquinoline.

\section{CONCLUSIONS}

Experiments were conducted to investigate the promotive effect of pyridine on the biodegradability of isoquinoline under denitrifying conditions. The effect of $\mathrm{pH}$ and temperature on the biodegradation of isoquinoline in the presence of pyridine were also investigated. $\mathrm{pH}$ and temperature significantly influenced the biodegradation of isoquinoline. At $\mathrm{pH}$ of 7.5, both isoquinoline and pyridine were completely removed, whereas at $\mathrm{pH}$ of 6.5 and 8.0 , isoquinoline was only removed by $84 \%$ and $86 \%$, respectively. The high $\mathrm{pH}$ even inhibited the degradation of pyridine. Pyridine was completely degraded in 
the temperature range of $20-35^{\circ} \mathrm{C}$, while isoquinoline was removed by $90 \%$ only in the temperature range of $28-30{ }^{\circ} \mathrm{C}$. When the concentration ratio of isoquinoline to pyridine was in the range of $10: 1$ and 2:1, pyridine accelerated the degradation of isoquinoline; however, pyridine exhibited inhibition effect on the biodegradation of isoquinoline when the ratio reached $1: 1$.

\section{ACKNOWLEDGMENT}

This work was supported by the National Natural Science Foundation of China (Grant no.50108009) and the State Key Laboratory of Pollution Control and Resource Reuse, China (Grant no. PCRRCF07001 and PCRRY08009).

\section{REFERENCES}

[1] G. K. Sims and E. J. O. Loughlin, " Degradation of pyridines in the environment," Crit. Rev. Env. Ctrl., vol. 19, pp. 309-340, 1989.

[2] J. E. Rogers, R. G. Rily, S. W. Li, M. L. O’ Melley, and B. L. Thomas, "Microbial transformation of alkyl pyridine in ground water," Water Air Soil Pollution, vol. 24, pp. 443-454, 1985.

[3] K. V. Padoley, A. S. Rajvaidya, T. V. Subbarao, and R. A. Pandey, "Biodegradation of pyridine in a completely mixed activated sludge process," Bioresour. Technol., vol. 97, pp. 1225-1236, Jul 2006.

[4] D. H. Lataye, I. M. Mishra, and I. D. Mall, "Removal of pyridine from aqueous solution by adsorption on bagasse fly ash," Ind. Eng. Chem. Res., vol. 45, pp. 3934-3943, 2006.

[5] D. Mohan, K. P. Sing, S. Sinha, and D. Gosh, "Removal of pyridine derivatives from aqueous solution by activated carbons developed from agricultural waste materials," Carbon, vol. 43, pp. 1680-1693, 2005.

[6] S. Fetzner, "Bacterial degradation of pyridine, indole, quinoline, and their derivatives under different redox conditions," Appl. Microbiol. and Biotechnol., vol. 49, pp. 237-250, Mar 1998.

[7] S. V. Mohan, S. Sistla, R. K. Guru, K. K. Prasad, C. S. Kumar, S. V. Ramakrishna, and P. N. Sarma, "Microbial degradation of pyridine using Pseudomonas sp and isolation of plasmid responsible for degradation," Waste Manage, vol. 23, pp. 167-171, 2003.
[8] K. V. Padoley, A. S. Rajvaidya, T. V. Subbarao, and R. A. Pandey, " Biodegradation of pyridine in a completely mixed activated sludge process," Bioresour. Technol. , vol. 97 pp. 1225-1236, 2006.

[9] Y. M. Li, G. W. Gu, J. F. Zhao, H. Q. Yu, Y. L. Qiu, and Y. Z. Peng, "Treatment of coke-plant wastewater by biofilm systems for removal of organic compounds and nitrogen," Chemosphere, vol. 52, pp. 997-1005, 2003.

[10] O. M. Ogunsola, "Decomposition of isoquinoline and quinoline by supercritical water," J. Hazard. Mater., vol. 74, pp. 187-195, 2000.

[11] B. Uma and S. Sandhya, "Pyridine degradation and heterocyclic nitrification by Bacillus coagulans," Can. J. Microbiol., vol. 43, pp. 595-598, Jun .1997.

[12] B. Uma and S. Sandhya, "Kinetics of pyridine degradation along with toluene and methylene chloride with Bacillus sp. in packed bed reactor," Bioprocess Eng, vol. 18, pp. 303-305, Apr 1998.

[13] V. H. Edwards, "The influence of high substrate concentrations on microbial kinetics," Biotechnol. Bioeng., vol. XII, pp. 679-712, 1970.

[14] S. G. Wang, X.W. Liu, H. Y. Zhang, W. X. Gong, X. F. Sun, and B. Y. Gao, " Aerobic granulation for 2,4-dichlorophenol biodegradation in a sequencing batch reactor,", Chemosphere, vol. 69, pp. 769-775, 2007.

[15] C. P. Leslie. Grady. Jr., B. F. Smets, and D. S. Barbeau, "Variability in kinetic parameters estimates:a review of possible causes and a proposed terminology," Water Res., vol. 30, pp. 742748, 1996.

[16] G. Wang and N. Bai, "Study on QSAR for general pollutants in organic industrial waste," Toxic Subst. Mech., vol. 16, pp. 315326, 1997.

[17] Y. M. Li, G. W. Gu, J. F. Zhao, and H. Q. Yu, "Anoxic degradation of nitrogenous heterocyclic compounds by acclimated activated sludge," Process Biochem., vol. 37, pp. 81-86, Sep 2001.

[18] "APHA, AWWA, WEF, Standard Methods for the Examination of Water and Wastewater,18th edn," American Public Health Association, Washington, DC, 1992.

[19] N. Velghe and A. Claeys, "Rapid spectorphotometric determination of nitrate with phenol," Analyst, vol. 108, pp. 1088$1022,1983$. 